\title{
Antitrypanosomal activity of Verbascum sinaiticum Benth. (Scrophulariaceae) against Trypanosoma congolense isolates
}

\author{
Ermias Mergia ${ }^{1}$, Workineh Shibeshi ${ }^{1}$, Getachew Terefe $^{2}$ and Tilahun Teklehaymanot ${ }^{3^{*}}$
}

\begin{abstract}
Background: African Trypanosomiasis is a neglected tropical disease with a large impact on the livelihood of the rural poor in Sub-Saharan Africa. The available drugs for managing this disease are old, expensive and are facing the problem of drug resistance. Thus, the aim of this study was to evaluate in vivo antitrypanosomal efficacy of aqueous and absolute methanol leaf extracts of Verbascum sinaiticum Benth. against Trypanosoma congolense field isolate.
\end{abstract}

Methods: Verbascum sinaiticum (Local name 'qetetina') is a biennial plant, and $60-150 \mathrm{~cm}$ tall. It is traditionally used to treat wound, stomachache, viral infection, cancer, sunstroke, fever, abdominal colic, diarrhea, hemorrhage, anthrax, and hepatitis. The efficacy of aqueous and absolute methanol leaf extracts of $V$. sinaiticum was evaluated in a randomized experiment with Swiss albino mice infected with $T$. congolense field isolate. The extracts were administered at doses of 100, 200 and $400 \mathrm{mg} / \mathrm{kg}$ by intraperitoneal injection for seven days at 12 Days Post-Infection (DPI) when the peak parasitaemia level was approximately $10^{8}$ trypanosomes $/ \mathrm{ml}$.

Parasitaemia, Packed Cell Volume (PCV), mean survival time and change in body weight were used as indices for monitoring the efficacy of the extracts. Diminazene ( $28 \mathrm{mg} / \mathrm{kg}$ ) was used as a positive control while $2 \%$ Tween was used as the negative control. Phytochemicals screening were conducted following standard methods.

Results: The extracts showed no toxicity effect in Swiss albino mice and had LD $_{50}$ above 2000 mg/kg. The phytochemicals screened in V. sinaiticum were alkaloids, flavonoids, glycoside, saponins, steroids, phenolic compounds, and tannins. The mice treated with absolute methanol leaf extract of $V$. sinaiticum at $400 \mathrm{mg} / \mathrm{kg}$ dose had significantly lower mean parasitaemia $(7.20 \pm 0.16)(p<0.001)$ as compared to the negative control group (8.82 \pm 0.12$)$ on day 14 of treatment. Animals treated with the same dose had significant $(p<0.001)$ higher PCV value and body weight and as well as the highest mean survival time of $40.20 \pm 0.31$ days as compared to the negative control at the end of the observation period.

Conclusion: This study established that Verbascum sinaiticum had trypanocidal activity. The crude extracts have partially eliminated trypanosomes in a dose-dependent manner. The study can be a basis for future in-depth analysis of the biologically active chemicals.

Keywords: Verbascum sinaiticum, Trypanosoma congolense, In vivo, Phytochemical, Ethiopia

\footnotetext{
*Correspondence: tilahunmt@yahoo.com

${ }^{3}$ Aklilu Lemma Institute of Pathobiology, Addis Ababa University, Addis

Ababa, Ethiopia

Full list of author information is available at the end of the article
} 


\section{Background}

African Animal Trypanosomiasis (AAT) is a neglected tropical disease caused by Trypanosoma brucei brucei, $T$. vivax, and T. congolense while human Trypanosomiasis is caused by two subspecies of Trypanosoma brucei: $T$. brucei gambiense, and T. brucei rhodesiense [1, 2]. The disease has an enormous economic impact in Africa since it affects the settlement patterns of people including land use and farming [3,4]. In Ethiopia, AAT is one of the most significant and costly diseases because it hinders the effort made by the government to attain food sufficiency and affect the greater river basins of Abay, Omo, Ghibe, and Baro that have a high potential for agricultural development [5-8].

Trypanocides are used for the control of the disease in 37 African countries where animal trypanosomiasis is endemic but the available drugs are old, expensive, less effective, and face the problem of drug resistance [9-11]. The continued use of the same Trypanocides for years has resulted in drug resistance that has been largely responsible for the current chemotherapeutic failures in Ethiopia $[9,12]$. Therefore, there is a need to develop alternative and efficacious drugs, either synthetically or from plant origins.

Herbal remedies are known to have been used for the treatment of this disease such as. Khaya senegalensis, Piliostigma reticulatum, Securidaca longepedunculata, Ximenia americana and Artemisia abyssinica [2, 13, 14] and are strongly trypanocidal to T. $b$. brucei and T. congolense. In Ethiopia, recent reports indicated that some medicinal plants have antitrypanosomal activity and the potentials of many of these plants are yet to be investigated and claims to be tested [15-19]. Thus, this study was designed to determine the in vivo antitrypanosomal activity of $V$. sinaiticum against $T$. congolense infected mice. This study will also seek to validate results from the previous study by Mergia et al. [20] that gave indications of in vitro antitrypanosomal activity of methanol crude leaf extracts of $V$. sinaiticum against $T$. congolense field isolate.

Verbascum sinaiticum is traditionally used as a treatment for wound, stomachache [21]; viral infection, cancer [22]; sunstroke fever, abdominal colic, diarrhea, hemorrhage, anthrax [23]; hepatitis; and as hepatoprotective [24, 25]. Moreover, powder leaf of $V$. sinaiticum mixed with water is given orally $[22,26]$ and the filtrate is added to left ear and nose of animals [23] for the treatment of animal trypanosomiasis. The species in genus Verbascum are well-known drugs in folk medicines.

\section{Methods}

\section{Reference drug and chemicals}

The commercial trypanocidal drug used was diminazine aceturate $\left(\right.$ Veriben $^{\bullet}$ containing $1.05 \mathrm{~g}$ diminazine aceturate $+2.36 \mathrm{~g}$ antipyrine, (Ceva Santé Animale, France; batch number- 719A1).

\section{Plant material \\ Collection of plant specimen}

Voucher specimens and fresh leaves of $V$. sinaiticum were collected, in March 2013, from Entoto-mountain about $10 \mathrm{~km}$ north of Addis Ababa, Ethiopia. The taxonomic identification was done by an expert using Taxonomic keys and herbaria samples and deposited (Collection EM/002) at the National Herbarium of Addis Ababa University. The fresh leaf samples were prepared by air drying, grinding, and kept in plastic bags until required.

\section{Preparation and storage of extracts}

The aqueous and absolute methanol extracts were prepared by macerating $200 \mathrm{~g}$ of dried leaf powder of $V$. sinaiticum with $1000 \mathrm{ml}$ of each solvent for $48 \mathrm{~h}$. After filtering using Whattman No. 3 filter paper (Whattman Ltd., England), the aqueous extract was placed on a Petri dish and lyophilized for seven days to yield a solid residue. The absolute methanol extract was dried using Rotavapor (BÜCHI Rotavapor, Switzerland) at about $40^{\circ} \mathrm{C}$. The dried and powder samples of each were weighed and packed in glass vials and stored in desiccators over silica gel until required for use. The percentage yield was calculated as:

$$
\text { Percentage yield }=\frac{\text { Amount of extract obtained }}{\text { Amount of initial sample }} \times 100 \%
$$

\section{Phytochemical screening}

Aqueous and absolute methanol extracts of $V$. sinaiticum were screened for the presence of phytochemical following standard methods: alkaloids, phenolic compounds [27, 28], Anthraquinones [29], flavonoids [30], glycoside, saponins, tannins [31], Steroids, and terpenes [32].

\section{Study site selection and test organism}

The selection of the study site was based on the information from the National Tsetse and Investigation and Control Centre (NTTICC), and the National Animal Health Diagnostic and Investigation Center (NAHDIC) located in Bedele town, and previous reports on the prevalence of animal trypanosomiasis in the area [20,33-35]. The test organism, T. congolense was acquired from infected cattle at Sebategna kebele of Ilu-Aba-Bora-Zone, $480 \mathrm{~km}$ South West of Addis Ababa where the cattle in this area are known for drug resistance in cattle. However, the sensitivity of the test organism to existing drugs was not known. The blood sample was collected by NTTICC expert from the peripheral ear vein of each animal following the methodology in Mergia et al. [36]. The presence of $T$. congolense was detected by Microhaematocrit Buffy 
Coat Technique (MHBCT) [37] and Murray et al. [38]. Blood from the jugular vein of an animal with peak parasitaemia of $\left(\sim 10^{8}\right.$ trypanosomes/ml) [39] was collected to the ethylene diamine tetra acetic acid (EDTA) coated tube and diluted with PBS. Then $0.2 \mathrm{ml}$ of blood $\left(\sim 10^{4}\right.$ trypanosomes $\left./ \mathrm{ml}\right)$ was injected intraperitoneally to six laboratory mice and transported to Aklilu Lemma Institute of Pathobiology, Addis Ababa University for serial passage to other mice. About $0.2 \mathrm{ml}$ of blood collected from the donor mice containing $\left(\sim 10^{4}\right.$ trypanosomes $\left./ \mathrm{ml}\right)$ [39] was injected intraperitoneally into mice that were acclimatized to laboratory conditions and were used for in vivo evaluation of the crude leaf extracts of $V$. sinaiticum [36].

\section{Experimental animals}

Healthy Swiss albino mice (weighing 20-30 g and age of 8-12 weeks) were obtained from the Ethiopian Health and Nutrition Research Institute and School of Pharmacy, Addis Ababa University. Animals were housed in polypropylene cages (6-10 animals per cage), maintained under $12 \mathrm{hr}$ light/dark cycle and allowed free access to a pellet diet and clean water ad libitum. All procedures comply with the guide for the care and use of laboratory animals [39-41].

\section{Determination of acute toxicity}

The acute toxicity study was conducted in two phases, each with nine female Swiss albino mice. After seven days of adaptation, each extract, aqueous and methanol was dissolved in $2 \%$ Tween 80 in sterile water and given through intraperitoneal route. In the first phase, three groups, each with three mice were given 10, 100, and $1000 \mathrm{mg} / \mathrm{kg}$ body weight of doses of each extract, respectively. In the second phase, three mice within each group were given 1600, 2900, and $5000 \mathrm{mg} / \mathrm{kg}$ doses of each extract, respectively to determine the appropriate lethal dose $\left(\mathrm{LD}_{50}\right)$ value. Also, a third group of six mice (three mice for each phase) was set up as a control group and received the reconstituting solvent $2 \%$ Tween 80 in sterile water. All animals were kept under strict observation for behavioral, neurological, autonomic or physical changes such as alertness, motor activity, restlessness, convulsions, coma, diarrhea and lacrimation for $24 \mathrm{~h}$, with special attention during the first four hours. These observations continued for further 14 days for any signs of overt toxicity. Then the lowest dose, which killed one mouse (minimum toxic dose) and the highest dose, which had not killed any mouse (maximum tolerated dose) were noted, and the geometric mean of these two doses gave $\mathrm{LD}_{50}$. The $\mathrm{LD}_{50}$ was computed using the formula:

$$
\mathrm{LD}_{50}=\sqrt{\text { Minimum Toxic Dose } \times \text { Maximum Tolerated Dose }}
$$

\section{Determination of in vivo antitrypanosomal activities}

Parasite inoculation and extracts administration

Forty healthy Swiss albino mice infected intraperitoneally with $0.2 \mathrm{ml}$ of $T$. congolense infected blood ( $\sim 10^{4}$ trypanosomes $/ \mathrm{ml}$ ) were used to test trypanocidal activities of aqueous and methanol extracts. The mice were randomly divided into eight groups each comprising of 5 mice. The treatment of mice with the extracts in each group began on the 12th day of post-infection (day 0 of treatment) when the infected mice showed peak parasitaemia $\left(\sim 10^{8}\right.$ trypanosomes $/ \mathrm{ml}$ ). Group I-III were given $V$. sinaiticum aqueous extract (VSAE) of 100, 200, $400 \mathrm{mg} / \mathrm{kg}$; group IVVI were given $V$. sinaiticum methanol extract (VSME) of 100, 200, $400 \mathrm{mg} / \mathrm{kg}$, respectively. The positive control, group VII was treated with diminazine aceturate (Veriben ${ }^{\circ}$ ) (DA28) at a single dose of $28 \mathrm{mg} / \mathrm{kg}$ bwt while for the negative control, group VIII was given $2 \%$ Tween 80 (TW80). On each day of drug administration, the aqueous and methanol extracts of $V$. sinaiticum were freshly prepared by solubilizing in $2 \%$ Tween- 80 in sterile water and administered intraperitoneally in the morning consecutively for seven days. The doses were selected based on the acute toxicity study. The middle dose was one tenth of the lethal dose $(\sim 2000 \mathrm{mg} / \mathrm{kg})$, higher dose was twice the middle dose, and the lower dose was half of the middle dose [41].

\section{Determination of parasitaemia}

A drop of blood obtained from a mouse by tail snipping was used to make smears on the slides and to monitor parasitaemia every other day microscopically at $400 \times$ total magnification. The degree of parasitaemia was determined using the "Rapid Matching" method of Herbert and Lumsden [38]. The wet smear was prepared in triplicates from each animal, and the mean value of slide counts was taken per sample examined microscopically. Logarithm values of these counts were obtained by matching with the table given by Herbert and Lumsden [38].

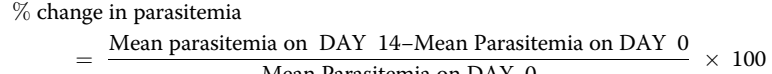

\section{Determination of packed cell volume (PCV)}

Packed cell volume was measured using Wintrobe and Landsberg [42], and Wernery et al. [43] methods to predict the effectiveness of the test extracts in preventing hemolysis resulting from increasing parasitaemia associated with trypanosomiasis. It was monitored for infection three times until the 14th day (on day $0,7,14$ ). 12 DPI was an important day to monitor since the treatment of mice with the extracts in each group began on the 12th day of post-infection (day 0 of treatment) 
when the infected mice showed peak parasitaemia $\left(\sim 10^{8}\right.$ trypanosomes $\left./ \mathrm{ml}\right)$. The effect of extracts in improving the PCV of treated animals was compared with the controls.

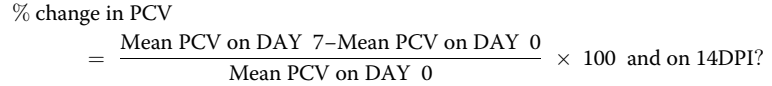

\section{Determination of body weight}

The body weight (in gram) of each mouse in all groups was measured before infection, on the day treatment commenced (day 0) and every other day (on Day 2, Day 4, Day 6, Day 8, Day 10, Day 12 and Day 14) up to day 14.

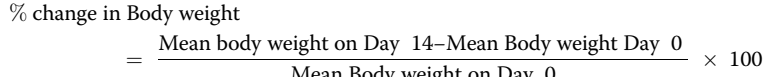

\section{Determination of mean survival time}

Mortality was monitored daily and the number of days from the date of inoculation of the parasite to death was recorded for each mouse in the treatment and control groups throughout the follow-up period for six weeks. The Mean Survival Time (MST) for each group was calculated as follows;

$$
\text { Mean survival time }=\frac{\text { Sum of survival time of all mice in a group }(\text { days })}{\text { Total number of mice in that group }}
$$

\section{Data analysis}

The data obtained from the study were summarized and expressed as mean \pm standard error of mean (SEM). Data analysis was performed using Statistical Package for Social Science (SPSS), version 17.0. One-way ANOVA followed by Tukey's multiple comparison tests were carried out to compare the results obtained from different groups and to determine statistical significance. $\mathrm{P}$ values less than 0.05 were considered significant.

\section{Results}

\section{Yield for plant extract and phytochemical screening}

The aqueous and methanol leaf extracts of $V$. sinaiticum gave $13.09 \% \mathrm{w} / \mathrm{w}$ and $18.13 \% \mathrm{w} / \mathrm{w}$ respectively. The phytochemical screening results are shown in Table 1 . The methanol extract had more phytochemicals compared to the aqueous extract; however, anthraquinones and terpenes were absent in both extracts.

\section{Acute toxicity test}

The acute toxicity bioassay showed that the Lethal Dosage $\left(\mathrm{LD}_{50}\right)$ of the aqueous $\left(\mathrm{LD}_{50}=3807.9 \mathrm{mg} / \mathrm{kg}\right.$ ) and methanol $\left(\mathrm{LD}_{50}=2154.1 \mathrm{mg} / \mathrm{kg}\right)$ leaf extracts of $V$. sinaiticum was above $2000 \mathrm{mg} / \mathrm{kg}$ and there was no
Table 1 Phytochemicals screened from the aqueous and methanol leaf extracts of Verbascum sinaiticum

\begin{tabular}{lll}
\hline Constituents & V. sinaiticum & \\
\cline { 2 - 3 } & Aqueous extract & Methanol extract \\
\hline Alkaloids & + & + \\
Anthraquinones & - & - \\
Flavonoids & - & + \\
Glycoside & - & + \\
Saponins & + & - \\
Steroids & - & + \\
Phenolic compounds & - & + \\
Tannins & - & + \\
Terpenes & - & - \\
\hline$+=$ present, & &
\end{tabular}

evidence of an acute toxicity at the doses tested indicating good safety margin.

\section{In vivo antitrypanosomal activity of aqueous and methanol crude extracts \\ Effect on parasitaemia}

The reduction of parasitaemia showed variation among the administered doses of aqueous and methanol extracts of $V$. sinaiticum. The animals treated with $400 \mathrm{mg} / \mathrm{kg}$ dose of the aqueous extract had significantly $(p<0.001)$ low level of parasitaemia on days 8 and 10 when compared with other doses of the aqueous extract treated mice. The methanol leaf extract of $V$. sinaiticum at $100 \mathrm{mg} / \mathrm{kg}$, $200 \mathrm{mg} / \mathrm{kg}$ and $400 \mathrm{mg} / \mathrm{kg}$ had kept parasitaemia at a significantly low level on day 6, 8, 10, 12 and $14(p<0.001)$ as compared with the negative control (Table 2 ).

\section{Effect on packed cell volume}

Animals treated with a higher dose $(400 \mathrm{mg} / \mathrm{kg})$ of the aqueous extract of $V$. sinaiticum had a statistically significant $(p<0.001)$ higher PCV value $(47.14 \pm 0.25)$ as compared to the negative control group $(40.58 \pm 0.28)$ on day 14 of treatment. Analysis of change in the percentage of PCV from day 7 to day 14 of treatment also showed that the aqueous extract at 200 and $400 \mathrm{mg} / \mathrm{kg}$ dose had prevented a drop in PCV associated with trypanosomes as compared to the negative control group (Table 3). In consistence with the results seen in PVC (Fig. 1), animals treated with the methanol extract of $V$. sinaiticum had higher PCV value $(p<0.001)$ as compared to the negative control groups at the end of the observation period (Table 3).

\section{Effect on body weight}

The aqueous and methanol extracts of $V$. sinaiticum were capable of improving body weight of treated animals on days $8-14$ as compared to the negative control group 
Table 2 The effect of aqueous and methanol leaf extracts of Verbascum sinaiticum on parasitaemia level of Trypanosoma congolense infected mice

\begin{tabular}{|c|c|c|c|c|c|c|c|c|}
\hline \multirow[t]{2}{*}{ Days } & \multicolumn{8}{|c|}{ Parasitaemia level (log number/ml) } \\
\hline & $\mathrm{DA} 28$ & TW80 & VSAE100 & VSAE200 & VSAE400 & VSME100 & VSME200 & VSME400 \\
\hline Day0 & $7.68+0.18$ & $7.44+0.17$ & $7.32+0.07$ & $7.08+0.07$ & $7.31+0.11$ & $7.44+0.11$ & $7.08+0.15$ & $7.32+0.12$ \\
\hline Day2 & $0.00+0.00^{\mathrm{d} * * *}$ & $7.74+0.17$ & $7.56+0.11$ & $7.44+0.11$ & $7.56+0.11$ & $7.68+0.12$ & $7.56+0.11$ & $7.62+0.12$ \\
\hline Day4 & $0.00+0.00^{\mathrm{d} * * *}$ & $7.86+0.11$ & $7.50+0.09$ & $7.80+0.13$ & $7.32+0.07^{a * *, c *}$ & $7.50+0.16$ & $7.32+0.07^{\mathrm{a} *}$ & $7.26+0.11^{a * *}$ \\
\hline Day6 & $0.00+0.00^{\mathrm{d} * * *}$ & $8.16+0.11^{d_{* * *}}$ & $7.32+0.00^{\mathrm{a} * * *}$ & $7.44+0.17^{\mathrm{a} * * *}$ & $7.14+0.11^{a * * *}$ & $7.44+0.11^{\mathrm{a} * * *}$ & $7.02+0.07^{a_{* * *} b_{*}}$ & $6.96+0.11^{a_{* * *}, b_{*}}$ \\
\hline Day8 & $0.00+0.00^{\mathrm{d} * * *}$ & $8.28+0.07^{\mathrm{d} * * *}$ & $7.44+0.06^{\mathrm{a***}}$ & $7.38+0.07^{a * * *}$ & $6.78+0.12^{d * * *}$ & $7.68+0.12^{\mathrm{a***}}$ & $6.66+0.06^{\mathrm{ab} * * *}$ & $6.54+0.11^{\mathrm{ab} * * *}$ \\
\hline Day 10 & $0.00+0.00^{\mathrm{d} * * *}$ & $8.52+0.12^{d * * *}$ & $7.74+0.11^{\mathrm{a} * * *}$ & $7.62+0.07^{\mathrm{a***}}$ & $7.08+0.12^{d * * *}$ & $7.86+0.11^{\mathrm{a} * * *}$ & $7.14+0.11^{\mathrm{ab} * * *}$ & $6.36+0.17^{\mathrm{abc***}}$ \\
\hline Day 12 & $2.16+1.32^{d_{* * *}}$ & $8.64+0.06$ & $8.04+0.11$ & $7.92+0.12$ & $7.56+0.11$ & $7.98+0.07$ & $7.44+0.11$ & $6.72+0.20$ \\
\hline Day14 & $5.52+0.07^{d * * *}$ & $8.82+0.12$ & $8.40+0.09$ & $8.16+0.11^{\mathrm{a} * * *}$ & $8.04+0.11^{a * * *}$ & $8.28+0.07^{\mathrm{a} *}$ & $7.74+0.11^{a * * *, b *}$ & $7.20+0.16^{a b * * *, c *}$ \\
\hline
\end{tabular}

Values are in Mean $\pm \mathrm{SEM} ; \mathrm{N}=5 ; D A 28$ diminazine aceturate $28 \mathrm{mg} / \mathrm{kg}$-the positive control; VSAE V. sinaiticum aqueous extract; ${ }^{\mathrm{a}}$ compared to TW80 = $2 \%$ tween

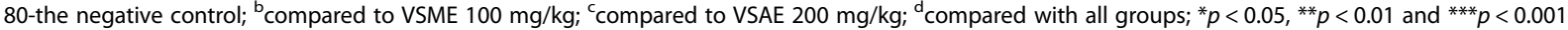

$(p<0.001)$. Animals treated with $400 \mathrm{mg} / \mathrm{kg}$ dose of both extracts of $V$. sinaiticum had a significantly $(p<$ 0.001 ) higher body weight as compared to the negative control group $(19.09 \pm 0.34)$ on day 14 of treatment (Fig. 2).

\section{Effect on mean survival time}

Animals treated with $400 \mathrm{mg} / \mathrm{kg}$ of the methanol extract of $V$. sinaiticum had the highest mean survival time (40.20 \pm 0.31 days) as compared to the negative control group $(25.40 \pm 0.43)$ while animals that received the positive control diminazine aceturate had a mean survival time of $44.00 \pm 0.63$ days (Fig. 3).

The overall activities of the extracts are shown in Fig. 4. The extracts had shown an increased values in the indices used for studying the potential of Verbascum sinaiticum against Trypanosoma congolense infected mice. The PVC and survival time had higher values as compared to negative control.

\section{Discussion}

The Verbascum sinaiticum extracts showed an $\mathrm{LD}_{50}$ above $2000 \mathrm{mg} / \mathrm{kg}$ indicating there was no lethal effect.
The results validate why the plant has been used by several traditional healers for treatment of various disease including animal trypanosomiasis [21-24, 26], and toxicity and antidotes have not been reported. The experimental determination of this safety margin would justify that the plant is safe at the dose levels used in this study, which is an additional proof of the medicinal value of the plant in folk medicine. Though in previous studies, phytochemicals flavonolignans, hydrocarpin, sinaiticin, as well as two flavones, chrysoeriol and luteolin from the leaf of $V$. sinaiticum exhibited dose-dependent cytotoxicity when tested against cultured P-388 cells [44].

The trypanocidal and trypanostatic efficacy of $V$. sinaiticum aqueous and methanol extracts are associated with the presence of one or more biological active principals. This was shown to be true by the positive test for the presence of alkaloids, flavonoids, phenols, glycosides, saponins, steroids, and tannins. Tatli et al. [45] reported that Verbascum L. species has considerable saponins, iridoid and phenylethanoid glycosides, monoterpene glucoside, neolignan glucosides, flavonoids, steroids and spermine alkaloids that are responsible for biological activities thus their use in folk medicines. Previous in vitro and in vivo studies conducted

Table 3 Effect of the aqueous and methanol leaf extracts of Verbascum sinaiticum on packed cell volume of Trypanosoma congolense infected mice

\begin{tabular}{|c|c|c|c|c|c|c|c|c|}
\hline \multirow[t]{2}{*}{ Days } & \multicolumn{8}{|l|}{ PCV Values } \\
\hline & DA28 & TW80 & VSAE100 & VSAE200 & VSAE400 & VSME100 & VSME200 & VSME400 \\
\hline Pre-infection & $51.18 \pm 0.37$ & $50.88 \pm 0.14$ & $51.38 \pm 0.18$ & $51.18 \pm 0.24$ & $51.44 \pm 0.12$ & $51.22 \pm 0.19$ & $51.30 \pm 0.27$ & $51.48 \pm 0.23$ \\
\hline Day 0 & $49.40 \pm 0.23$ & $49.04 \pm 0.29$ & $49.10 \pm 0.19$ & $49.18 \pm 0.18$ & $49.24 \pm 0.16$ & $49.20 \pm 0.22$ & $49.24 \pm 0.17$ & $48.88 \pm 0.20$ \\
\hline Day 7 & $48.88 \pm 0.25^{d_{* *}}$ & $44.78 \pm 0.37$ & $44.78 \pm 0.36$ & $46.08 \pm 0.32^{a *, b *}$ & $48.24 \pm 0.18^{a b c^{* *}}$ & $44.76 \pm 0.27$ & $47.40 \pm 0.41^{a b_{* *}}$ & $47.56 \pm 0.16^{a b_{* *}}$ \\
\hline $\begin{array}{l}\text { \%change PCV } \\
\text { day } 7-0\end{array}$ & -1.05 & -8.69 & -8.79 & -6.3 & -2.03 & -9.02 & -3.73 & -2.7 \\
\hline Day 14 & $50.08 \pm 0.15^{d_{* *}}$ & $40.58 \pm 0.27^{d_{* *}}$ & $43.72 \pm 0.39^{a * *}$ & $45.32 \pm 0.37^{a^{* *}, b^{*}}$ & $47.14 \pm 0.25^{d_{* *}}$ & $44.30 \pm 0.32^{a * *}$ & $46.80 \pm 0.18^{a b_{* *}}$ & $46.88 \pm 0.35^{a b_{* *}}$ \\
\hline $\begin{array}{l}\% \text { change PCV } \\
\text { day } 7-14\end{array}$ & 2.45 & -9.38 & -2.36 & -1.65 & -2.28 & -1.02 & -1.09 & -1.59 \\
\hline
\end{tabular}

Values are expressed in Mean \pm S.E.M; $N=5 ;$ DA28 diminazine aceturate $28 \mathrm{mg} / \mathrm{kg}$ - the positive control; VSAE V. sinaiticum aqueous extract; ${ }^{a}$ compared to TW $80=2 \%$ tween 80 -the negative control; ${ }^{\text {b }}$ compared to VSAE $100 \mathrm{mg} / \mathrm{kg}{ }^{\mathrm{c}}$ compared to VSAE $200 \mathrm{mg} / \mathrm{kg}{ }^{\mathrm{d}}$ compared with all groups; ${ }^{*} p<0.05$ and ${ }^{* *} p<0.001$ 


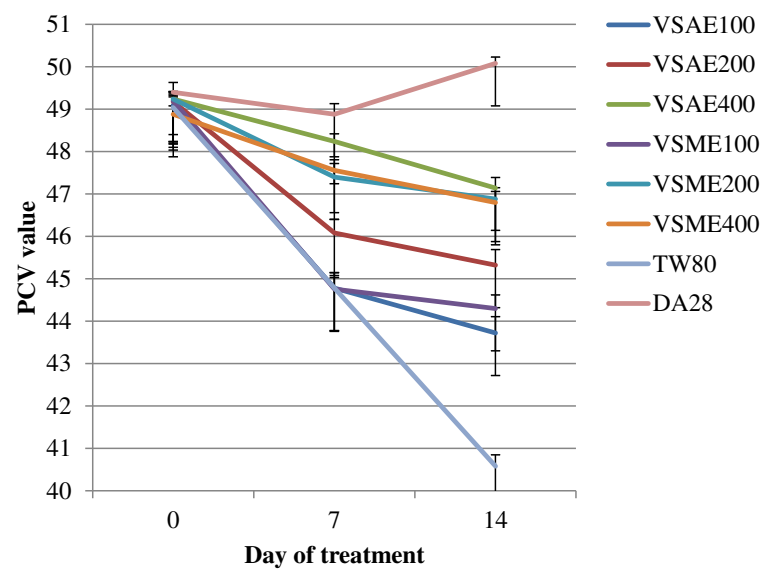

Fig. 1 Comparison of the effect of aqueous and methanol leaf extracts of Verbascum sinaiticum on packed cell volume of Trypanosoma congolense infected mice

on the antitrypanosomal activities of these phytochemicals have reported the trypanocidal and trypanostatic potential of these compound in human and animal trypanosomes $[14,15,46-48]$. Therefore, the observed in vivo antitrypanosomal activity of $V$. sinaiticum might be attributed either to the individual class of compounds antitrypanosomal activity or to the synergistic effect of each class of compounds in the extracts [49].

The reduction of parasitaemia $(6.36+0.17)$ and prolonging of the lifespan ( $40.20 \pm 0.31$ days $)$ of infected mice by a higher dose of methanol extract can be associated to the trypanosuppression of the phytochemical mainly the flavonoids that have been shown to exhibit potential to inhibit the growth of African Trypanosomes [14, 50]. These biologically active phytochemicals act at a single or multiple target sites associated with a physiological process [14] and interference with the redox balance of the parasites acting on the respiratory chain or on the cellular defenses against oxidative stress that partially eliminates the trypanosomes

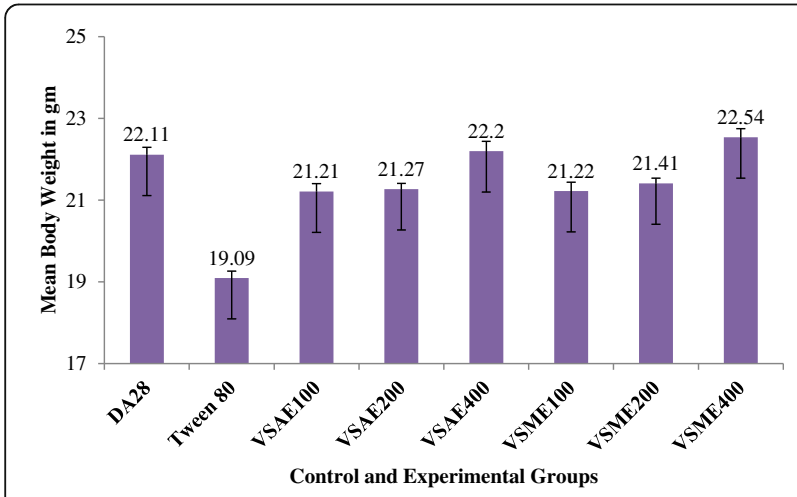

Fig. 2 Comparison of the effect of aqueous and methanol leaf extracts of Verbascum sinaiticum on body weight of Trypanosoma congolense infected mice
$[51,52]$. Moreover, the flavonoids compounds have demonstrated promising antitrypanosomal activities on the trypomastigote forms, which are usually found in the bloodstream of mammalians [53, 54]. Alkaloids, flavonoids, phenolics, and terpenes have shown trypanocidal activity in an in vitro investigation, and the alkaloids have been shown to reduce the growth of trypanosomes by intercalating in the deoxyribonucleic acid (DNA) of trypanosomes [13] and inhibiting protein synthesis [53].

The trypanosomes are not eliminated from the blood stream of infected mice though animals treated with $400 \mathrm{mg} / \mathrm{kg}$ methanol extract had significantly $(p<0.001)$ lower mean parasitaemia $(7.20+0.16)$ as compared to the negative control group $(8.82+0.12)$ on day 14 of treatment. This result is similar to other studies conducted on Khaya senegalensis [55], Artemisia abyssinica [56], Adansonia digitata [18], Garcinia kola [57] and Carrisa edulis [58] with antitrypanosomal activities. The efficacy of crude extract might be masked with high parasite load in the host animal $[55,59]$, or it could be due to enzymatic inactivation of active compounds of the phytochemical in the host animal and impaired absorption from the site of administration [52, 60]. In addition, the concentration of the phytochemicals that reaches the target organs, the duration the phytochemicals take to effect a cure, and short half-life of the phytochemicals can reduce the efficacy of the crude extracts [61].

The effectiveness of diminazine aceturate was challenged in all mice approximately on days $12-14$ of treatment and relapse of parasitaemia was observed [18]. T. congolense sequester in small vessels and capillaries of the heart, skeletal and other tissues, which often leads to a prolonged prepatent period [62]. The relapse is also a clue to the existence of drug resistance trypanosomes in the South West and North West part of the country since the samples were acquired from the south-west part of Ethiopia. The test organism obtained from south-west part of Ethiopia can be a heterogeneous population of trypanosomes that are sensitive and resistant to diminazine aceturate; hence, the treatment with diminazine aceturate could have eliminated the sensitive subpopulation through its therapeutic effects, so that the relapse is the manifestation of resistant population $[6,7,63]$.

The reduction in packed cell volume (PCV) observed in extracts treated mice compared to diminazine aceturate treated mice could be due to acute hemolysis induced by the growing infection and increased susceptibility of red blood cell membrane to oxidative damage [64]. A higher PCV exhibited in mice treated with the extracts compared with the negative control group might be as a result of the phytochemicals reducing the parasite load, neutralizing the toxic metabolites produced by trypanosomes; the aetiological factors involved in the haemolysis of red blood cells and scavenging the trypanosome associated free 


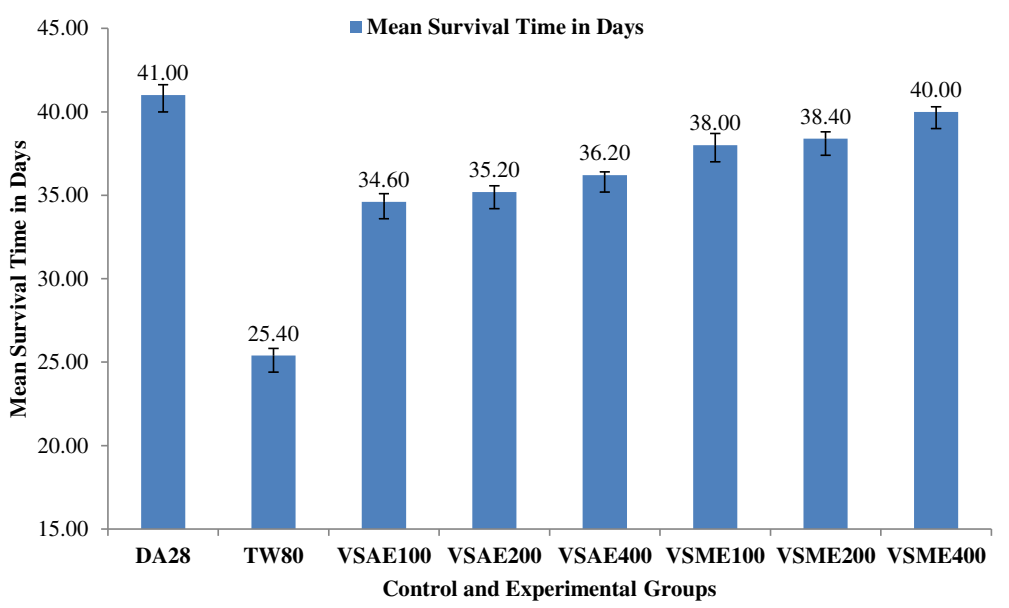

Fig. 3 Mean survival time of Trypanosoma congolense infected mice treated with aqueous and methanol crude leaf extracts of Verbascum sinaiticum

radicals $[59,65,66]$. It could also be attributed to the potential antioxidant activity of the flavonoids and glycosides present in the leaf, which was also confirmed by similar studies previously done on related plant species from the same family [67-69].

The loss of body weight is associated with progression of infection followed by appetite decreases, and the animal loses condition as a result, there is wasting. The decreased supply of oxygen because of the anemia is also an important factor [70, 71]. However, animals, which received $400 \mathrm{mg} / \mathrm{kg}$ aqueous and methanol extract of $V$. sinaiticum gained weight by 1.07 and $1.67 \%$ respectively, which was statistically significant $(p<0.001)$ as compared to the negative control groups. This shows that because of reduction in parasitaemia and prevention of drop in PCV as a result of the trypanosuppressive effect of the extracts against trypanosome infection, physical status of the treated mice was improved. Similar observations have been made by other researchers [59, 68, 69, 72-74].

\section{Conclusion}

In vivo tests usually show reliable antitrypanosomal activities of traditional antitrypanosomal medicinal plants. $V$. sinaiticum trypanocidal activity analysis indicated its antitrypanosomal potential and without toxicity effect on the host organism. The phytochemicals identified are known to have antitrypanosomal activities. The crude extracts have partially eliminated trypanosomes in a dose-dependent manner. Though unintentional, this study has also shown the existence of drug-resistant trypanosomes in the field stock. The study has shown that $V$. sinaiticum has a potential to be used as trypanocidal though further analysis is required to identify potent biologically active chemicals.

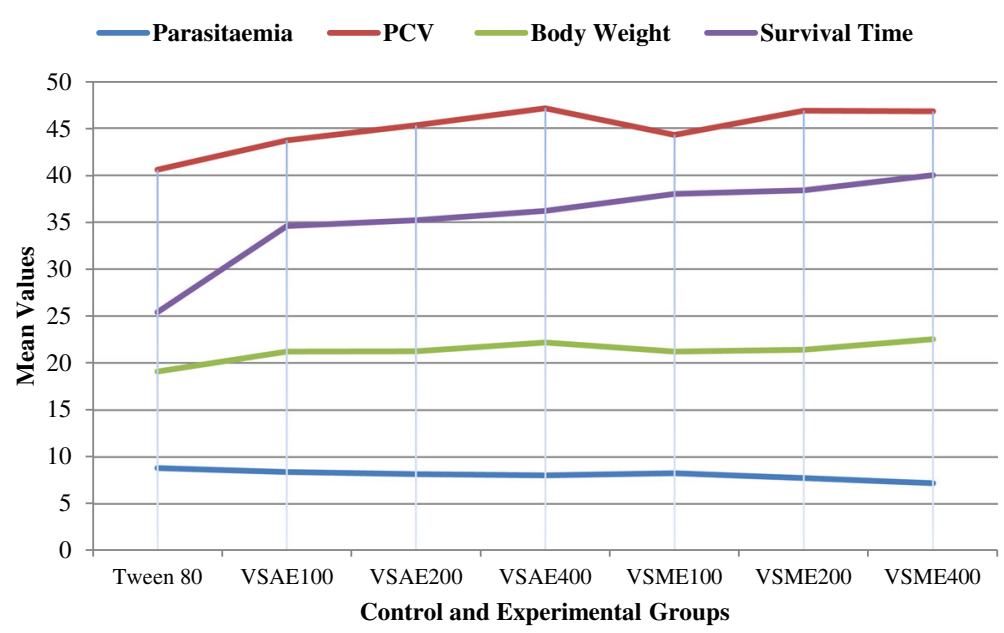

Fig. 4 Comparison of the effects of aqueous and methanol leaf extracts of Verbascum sinaiticum on parasitaemia, packed cell volume, body weight, and survival time of Trypanosoma congolense infected mice at the end of the experimental study 


\section{Abbreviations}

AAT: African Animal Trypanosomiasis; ANOVA: Analysis of Variance; bwt: Body weight; DA28: Diminazine aceturate $\left(\right.$ Veriben $\left.^{\circledR}\right)$; DNA: Deoxyribonucleic acid; DPI: Days Post-Infection; EDTA: Ethylene diamine tetra acetic acid; $\mathrm{LD}_{50}$ : Lethal dose; MHBCT: Microhaematocrit Buffy Coat Technique; MST: Mean survival time; NAHDIC: National Animal Health Diagnostic and Investigation Center; NTTICC: National Tsetse and Trypanosomosis Investigation and Control Centre; PCV: Packed cell volume; SEM: Standard error of mean; SPSS: Statistical Package for Social Science; TW80: Tween 80; VSAE: V. sinaiticum aqueous extract; VSME: V. sinaiticum methanol extract

\section{Acknowledgements}

The authors thank staff of the National Tsetse and Trypanosomosis Investigation and Control Centre for technical assistance during isolation of the test organism; Medical Parasitology staff of Aklilu Lemma Institute of Pathobiology for their cooperation and unreserved help during the laboratory work, and Vice President for Research and Technology Transfer Office of Addis Ababa University for funding the research under the framework of the Thematic Research Project.

\section{Funding}

The project was funded by the Vice President for Research and Technology Office, Addis Ababa University.

\section{Availability of data and materials}

The raw data will be freely available on request for non-commercial purposes though the majority of the data are found in the manuscript.

\section{Authors' contributions}

EM, WS, GT and TT conceived the study and drafted the manuscript. EM, WS, GT and TT participated in designing the study. All authors read and approved the final version of the manuscript.

\section{Competing interests}

The author(s) declare that they have no competing interests.

\section{Consent for publication}

Not applicable.

\section{Ethics approval and consent to participate}

The study was reviewed and approved by Institutional Review Board of Aklilu Lemma Institute of Pathobiology, Addis Ababa University.

\section{Author details}

'Department of Pharmacology and Clinical Pharmacy, Faculty of Health Sciences, Addis Ababa University, Addis Ababa, Ethiopia. ${ }^{2}$ Department of Parasitology, Faculty of Veterinary Medicine, Addis Ababa University, Addis Ababa, Ethiopia. ${ }^{3}$ Aklilu Lemma Institute of Pathobiology, Addis Ababa University, Addis Ababa, Ethiopia.

\section{Received: 14 February 2016 Accepted: 8 September 2016}

Published online: 15 September 2016

\section{References}

1. Mulaw S, Addis M, Fromsa A. Study on the prevalence of major trypanosomes affecting bovine in tsetse infested asosa district of benishangul gumuz regional state, Western Ethiopia. Glob Vet. 2011;7(4):330-6.

2. Feyera T, Terefe G, Shibeshi W. Phytochemical Screening and in vitro antitrypanosomal activity of the aerial parts of Artemisia abyssinica against Trypanosoma congolense Field Isolate. Ethiop Pharm J. 2011:29(2):137-42.

3. National Tsetse and Trypanosomosis Investigation and Control Centre NTTICC; http://nahdic.gov.et/node/64 accesses on 6 Apr 2016

4. FAO. Tsetse and Trypanosomosis information. 2015; 37(2). www.fao.org/3/ a-i4680e.pdf Accessed on 6 Apr 2016

5. Abebe G. Trypanosomosis in Ethiopia. Ethiop J Bio Sci. 2005;4:75-121.

6. Nigatu K, Abebe A. Trypanosomosis of cattle in selected districts of Awi zone, northwestern Ethiopia. Trop Anim Health Prod. 2009:41:1353-6.

7. Desta MR, Menkir S, Kebede A. Prevalence and seasonal incidence of bovine trypanosomosis in Birbir valley, Baro Akobo River system, Western Ethiopia. $J$ Vet Med Animal Health. 2013;5(5):138-43.

8. NTTICC. National Tsetse and Trypanosomosis Investigation and Control Center. Report for the period 7th June 2004-6th July 2004. Bedelle, p. 3.
9. Shiferaw S, Muktar Y, Belina D. A review on trypanocidal drug resistance in Ethiopia. JPVB. 2015;7(4):58-66.

10. Hotez PJ, Molyneuz DH, Fenwick A, Kumaresan J, Sachs SE, Sachs JD, Savioli L. Control of neglected tropical diseases. N Engl J Med. 2007;357:1018-27.

11. Geerts S, Delespaux V, Bossche V, Meded ZK. Drug resistance in trypanosomes of livestock: a worrying issue. Acad Overzeese Wet. 2010;55:177-4

12. Afewerk Y, Clausen PH, Abebe G, Tilahun G, Mehlitz D. Multiple- drug resistant $T$. congolence populations in village cattle of Metekel district, northwest Ethiopia. Acta Trop. 2000;76:231-8.

13. Atawodi SE, Bulus T, Ibrahim S, Ameh DA, Nok AJ, Mamman M, et al. In vitro trypanocidal effect of methanolic extract of some Nigerian Savannah plants. Afr J Biotechnol. 2003;2(9):317-21.

14. Maikai VA. Antitrypanosomal activity of flavonoid extracted from Ximenia americana stem bark. Int J Biol. 2011;3(1):1

15. Hoet S, Opperdoes F, Brun R, Quetin L. Natural products active against African trypanosomes: a step towards new drugs. Nat Prod Rep. 2004;21:353-64.

16. Samson W. Studying herbal remedies. N Engl J Med. 2005:353(4):337-9.

17. Wurochekke AU, Nok AJ. In vitro and in vivo antitrypanosomal activity of the leaf of Lawsonia inermis against Trypanosoma brucei brucei infection in mice. J Medical Sci. 2004;4:236-9.

18. Ibrahim H, Ogbadoyi E, Adamu K, Bello M, Yemisi I. Evaluation of antitrypanosomal activity of ethyl acetate extract of adansonia digitata seed extract in T. b. brucei infected albino mice. Int J Drug Res Tech. 2012;2(7):454-60

19. Shuaibu MN, Wuyep PTA, Yanagi T, Hirayama K, Ichinose A, Tanaka T, Kouno I. Trypanocidal activity of extracts and compounds from the stem bark of Anogeissus leiocarpus and Terminalia avicennoides. Parasitology. 2008;102(4):697-703.

20. Mergia E, Shibeshi W, Terefe G, Teklehaymanot T. Phytochemical screening and in vitro antitrypanosomal activity of aqueous and methanol leaf extract of verbascum sinaiticum (scrophulariaceae) against trypanosoma congolense field isolate. J Clin Exp Pathol. 2014:4:4

21. Teklehaymanot T, Giday M, Medhin G, Mekonnen Y. Knowledge and use of medicinal plants by people around Debre Libanos monastery in Ethiopia. J Ethnopharmacol. 2007;111:271-83.

22. Teklehaymanot T. Ethnobotanical study of knowledge and medicinal plants use by the people in Dek Island in Ethiopia. J Ethnopharmacol. 2009;124:69-78.

23. Weldegerima B, Teferra A, Muthuswamy R. Ethno-Veterinary use of medicinal plants by traditional healers in Dabat District, Northwestern Ethiopia. Phcog Mag. 2008:4((Suppl)15):93.

24. Yineger $H$, Kelbessa $E$, Bekele $T$, Lulekal E. Ethnoveterinary medicinal plants at bale mountains national park, Ethiopia. J Ethnopharmacol. 2007;112:55-70.

25. Umer S, Asres K, Veeresham C. Hepatoprotective activities of two Ethiopian medicinal plants. Pharm Biol. 2010;48(4):461-8.

26. Fullas F. Ethiopian medicinal plants in veterinary health care. Ethiopian e-journal for research and innovation, vol. 2. 2010. p. 48-58.

27. Rafauf R. Handbook of alkaloids and alkaloid containing plants. 2nd ed. New York: Academic; 1970.

28. Sofowora A. Medicinal plants and traditional medicine in Africa. New York: John Wiley and Sons Ltd; 1982. p. 256.

29. Tyler VE, Brady LR, Robbers JE. Pharmacognosy. 9th ed. Philadelphia: Lea and Febiger; 1988

30. Dermarderosian A, Liberti LE. Natural products medicine: A scientific guide to foods, drugs and cosmetics. 1st ed. Philadelphia: Geo. F. Stickley Co; 1988. p. 46-66.

31. Evans W. Pharmacognosy. 14th ed. USA: W.B. Saunders Ltd; 1996. p. 105-766.

32. Briggs $\mathrm{MH}$. Advances in steroid biochemistry and pharmacology. 4th ed. New York: Academic; 1970. p. 24.

33. Chaka H, Abebe $\mathrm{G}$. Drug resistant trypanosomes: a threat to cattle production in the Southwest of Ethiopia. Revue Élev Méd vét Pays trop. 2003:56(1-2):33-6.

34. Tasew S, Duguma R. Cattle anaemia and trypanosomiasis in western Oromia State. Ethiopia Revue Méd Vét. 2012:163(12):581-8.

35. Moti Y, Derara B, Dalasa D, Tasew S, Degefu H. Bovine trypanosomosis and gastrointestinal helminthosis in settlement villages of Bedele district, South-western Ethiopia. Ethiop Vet J. 2013;17(1):41-54.

36. Mergia E, Shibeshi W, Terefe G, Teklehaymanot T. Evaluation of In vivo antitrypanosomal activity of aqueous and methanol leaf extracts of Clutia abyssinica (Euphorbiaceae) against Trypanosoma congolense field isolate. Nat Prod Chem Res. 2014;2:138. doi:10.4172/2329-6836.1000138.

37. Woo PT. The haematocrit centrifuge technique for the diagnosis of African trypanosomiasis. Acta Trop. 1970;27:384-6. 
38. Murray M, Murray PK, Mcintyre WIM. An improved parasitological technique for the diagnosis of African trypanosomiasis. Trans R Soc Trop Med Hyg. 1977;71:325-6.

39. Herbert WJ, Lumsden WHR. Trypanosoma brucei: A rapid "matching" Method of estimating the host's parasitemia. Exp Parasitol. 1976;40:427-31.

40. ILAR [Institute for Laboratory Animal Research, National Research Council]. Humane endpoints for animals used in biomedical research and testing. ILAR J. 2000;41:59-123.

41. OECD. The organization of economic Co-operation and development: OECD guideline for the testing of chemicals. 2001.

42. Wintrobe MM, Landsberg JW. A standardized technique for the blood sedimentation test. Am J Med Sci. 1970;189:102-4.

43. Wernery $U$, Zachariah R, Mumford JA, Luckins T. Preliminary evaluation of diagnostic tests using horses experimentally infected with Trypanosoma evansi. Vet J. 2001;161:287-300.

44. Mohammed SA, Mamdouh MA, John MP, Douglas K. Cytotoxic flavonolignans and flavones from Verbascum sinaiticum leaves. Asian J Chem. 1999;11(4):1534-6.

45. Tatli II, Zeliha FAR. Chemical constituents of Verbascum L, species. FABAD J Pharm Sci. 2004:29:93-107.

46. Yabu Y, Yoshida A, Suzuki T, Nihei C, Kawai K, Minagawa N, et al. The efficacy of ascofuranone in a consecutive treatment on Trypanosoma brucei brucei in mice. Parasitol Int. 2003;52:155-64.

47. Harborne J, Williams C. Advances in flavonoid research since 1992 Phytochem. 2000;55:481-504.

48. Sawadogo WR, Le Douaron G, Maciuk A, Bories C, Loiseau PM, Figadère B, et al In vitro antileishmanial and antitrypanosomal activities of five medicinal plants from Burkina Faso. Parasitol Res. 2011. doi:10.1007/s00436-011-2699-3.

49. Mbaya AW, Ibrahim UI. In vivo and in vitro activities of medicinal plants on haemic and humoral trypanosomes: a review. Int J Pharmacol. 2011;7:1-11.

50. Wurochekke AU, Anyanwu GO. Antitrypanosomal activity of anogeissus leiocarpus in rats infected with Trypanosoma brucei brucei. Int Res J Biotechnol. 2012;3(1):005-9.

51. Merschjohann K, Sporer F, Steverding D, Wink M. In-vitro effect of alkaloids on bloodstream forms of Trypanosoma brucei and Trypanosoma congolense. Planta Med. 2001;67:623-7.

52. Antia RE, Olayemi JO, Aina OO, Ajaiyeoba EO. In vitro and in vivo animal model antitrypanosomal evaluation of ten medicinal plant extracts from south-west Nigeria. Afr J Biotechnol. 2009:8(7):1437-40.

53. Camacho MDR, Mata R, Castaneda P, Kirby GC, Warhurst DC, Croft SL, et al. Bioactive compounds from Celaenodendron mexicanum. Planta Med. 2000;66:463-8.

54. Grecco SS, Reimão JQ, Tempone AG, Sartorelli P, Romoff P, Marcelo JP, et al. Isolation of an antileishmanial and antitrypanosomal flavanone from the leaves of Baccharis retusa DC. (Asteraceae). Parasitol Res. 2010;106:1245-8.

55. Ibrahim MA, Njoku GC, Sallau AB. In vivo activity of stem bark aqueous extract of Khaya senegalensis against Trypanosoma brucei. Afr J Biotechnol. 2008;7(5):661-3.

56. Teka F, Getachew T, Workineh S. Evaluation of In vivo anti-trypanosomal activity of crude extracts of Artemisia abyssinica against a Trypanosoma congolense isolate. BMC Complement Altern Med. 2014;14:117.

57. Ogbadoyi E, Adamu Y, Omotosho R. Preliminary studies of the antitrypanosomal activity of Garcinia kola nut extract in mice infected with T. b. brucei. J Med Med Sci. 2011;2(1):628-31.

58. Wurochekke AU, Nuhu N, Anyanwu GO. Trypanocidal potential of Carrisa edulis in male wistar rats infected with T. Congolense. Am J Res Commun. 2014;2(1):234-44.

59. Ekanem JT, Kolawole OM, Abbah OC. Some biochemical and haematological effects of black seed (Nigella sativa) oil on Trypanosoma brucei infected rats. Afr J Biochem Res. 2008;2(2):45-50.

60. Mann A, Egwim EC, Banji B, Abdukadir N, Gbate M, Ekanem JT. Efficacy of Dissotis rotundifolia on Trypanosoma brucei brucei infection in rats. Afr J Biochem Res. 2009;3(1):5-8

61. Williams S, Saha L, Singha UK, Chaudhuri M. Trypanosoma brucei. Differential requirement of membrane potential for import of proteins into mitochondria in two developmental stages. Exp Parasitol. 2005;118(3):420-33.

62. Mbaya AW, Nwosu CO, Onyeyili PA. Toxicity and antitrypanosomal effects of ethanolic extract of Butyrospermum paradoxum (Sapotaceae) stem bark in rats infected with Trypanosoma brucei brucei and Trypanosoma congolense. J Ethnopharmacol. 2007;111:526-30.
63. Hagos A, Gewado A, Yacob HT. Sensitivity of Trypanosoma congolense field isolates in experimentally infected calves in Konso district, Southern Ethiopia to isomethamidium and diminazene. J Vet Med Animal Health. 2014;6(1):44-7.

64. Karori SM, Ngure RM, Wachira FN, Wanyoko JK, Mwangi JN. Different types of tea products attenuate inflammation induced in Trypanosoma brucei brucei infected mice. Parasitol Internat. 2008;57:325-33.

65. Mpiana PT, Tshibanga DS, Shetonde OM, Ngbolua KN. In vitro antidrepanocytary activity (antisickle cell anaemia) of some Congolese plants. Phytomedicine. 2007;14:192-5

66. Ogoti P, Magiri E, Auma J, Magoma G, Imbuga M, Murilla G. Evaluation of In vivo antitrypanosomal activity of selected medicinal plant extracts. J Med Plant Res. 2009;3(11):849-54.

67. Akdemir ZS, Tatli II, Bedir E, Khan IA. Iridoid and phenylethanoid glycosides from Verbascum lasianthum. Turk J Chem. 2004;28:227-34.

68. Inabo HI, Fathuddin MM. In vivo antitrypanosomal potentials of ethyl acetate leaf extracts of Punica granatum against T. b. brucei. Adv Agric Biotechnol. 2011;1:82-6.

69. Umar IA, Ibrahim MA, Fari NA, Isah S, Balogun DA. In vitro and in vivo antiTrypanosoma evansi activities of extracts from different parts of Khaya senegalensis. J Cell Animal Biol. 2010;4(6):91-5.

70. Holmes PH, Katunguka E, Bennison J, Wassink G, Parkins J. Impact of nutrition on the pathophysiology of bovine trypanosomosis. Parasitology. 2000;120:S73-85.

71. Yusuf $A B$, Umar IA, Musa UB, Nok AJ. Screening of Vernonia amygdalina and Hymenocardia acida extracts and 1,3-diaminopropane for their antitrypanosomal activities: in vitro model. J Med Plants Res. 2012;6(19):3573-8.

72. Abubakar A, lliyasu B, Yusuf AB, Igweh AC, Onyekwelu NA, Shamaki BU, et al. Antitrypanosomall and haematological effects of selected Nigerian medicinal plants in Wistar rats. Biokemistri. 2005;17:95-9.

73. Adamu M, Nwosu CO, Igbokwe IO. Toxicity and phytochemical constituents of aqueous extract of ocimum gratissimum leaf. Nig Vet J. 2008;29(3):48-57.

74. Alli LA, Okochi VI, Adesoken AA. Antitrypanosomal activity and hematological effects of aquous extract of leaves of Morinda Lucida on Trypanosoma brucie brucie infected rats. Asian Jpharmhea Sci. 2011;1(3):111-5.

\section{Submit your next manuscript to BioMed Central and we will help you at every step:}

- We accept pre-submission inquiries

- Our selector tool helps you to find the most relevant journal

- We provide round the clock customer support

- Convenient online submission

- Thorough peer review

- Inclusion in PubMed and all major indexing services

- Maximum visibility for your research

Submit your manuscript at www.biomedcentral.com/submit 